\title{
Secondary Ion Emission Mass Spectrometry of Weathered Plagioclase in Volcanic Ash Soils
}

\author{
Michi Aratani* and Kazue Tazaki**
}

(Received November 10, 1977)

\begin{abstract}
Measurements were made by means of secondary ion emission mass spectrometry on weathered plagioclase in volcanic ash soils. Layers from the weathered surface to the fresh bulk were examined under a moderate condition peeling, where energies and intensities of peeling ions were carefully maintained as low as possible not to give the sample any disturbances except peeling. The results obtained on the layers from the top surafce to the bulk were in good agreement with those by scanning electron microscopy (SEM) with respect to the surface and those by electron probe microanalysis (EPMA) with respect to the bulk.
\end{abstract}

Some of the results were presented partly at the related meetings. ${ }^{1-3}$ )

\section{Introduction}

Plagioclase, one of sodium calcium aluminosilicates, is widely distributed in various kinds of soils, especially in volcanic ash soils, all over the earth. Its weathered surface is in some cases regarded as an index to give information about the history of the plagioclase and its surrounding. Relationship between weathering stage and micromorphology of plagioclase was investigated by means of SEM and EPMA by Tazaki.4) Relationship between the micromorphology of plagioclase and natural origin alpha-ray flux from the volcanic ash soils was reported by Tazaki, Aratani and Otsuka. ${ }^{1)}$ Here is described difference in secondary ion emission for two pieces of plagioclase with origins in contrast to each other under the moderate condition peeling.

\section{Samples}

Two pieces of plagioclase derived from different kinds of Daisen pumice (volcanic ash) were examined in the present measurement. One was from the middle Daisen pumice collected ${ }^{4}$ at Okachi, Kurayoshi City, Tottori Pref. The other was from the

* Laboratory of Nuclear Analytical Chemistry, The Institute of Physical and Chemical Research, (Wako-shi, Saitama, 351, Japan)

**The Institute for Thermal Spring Research, Okayama University, (Misasa, Tottori, 682-02, Japan) 

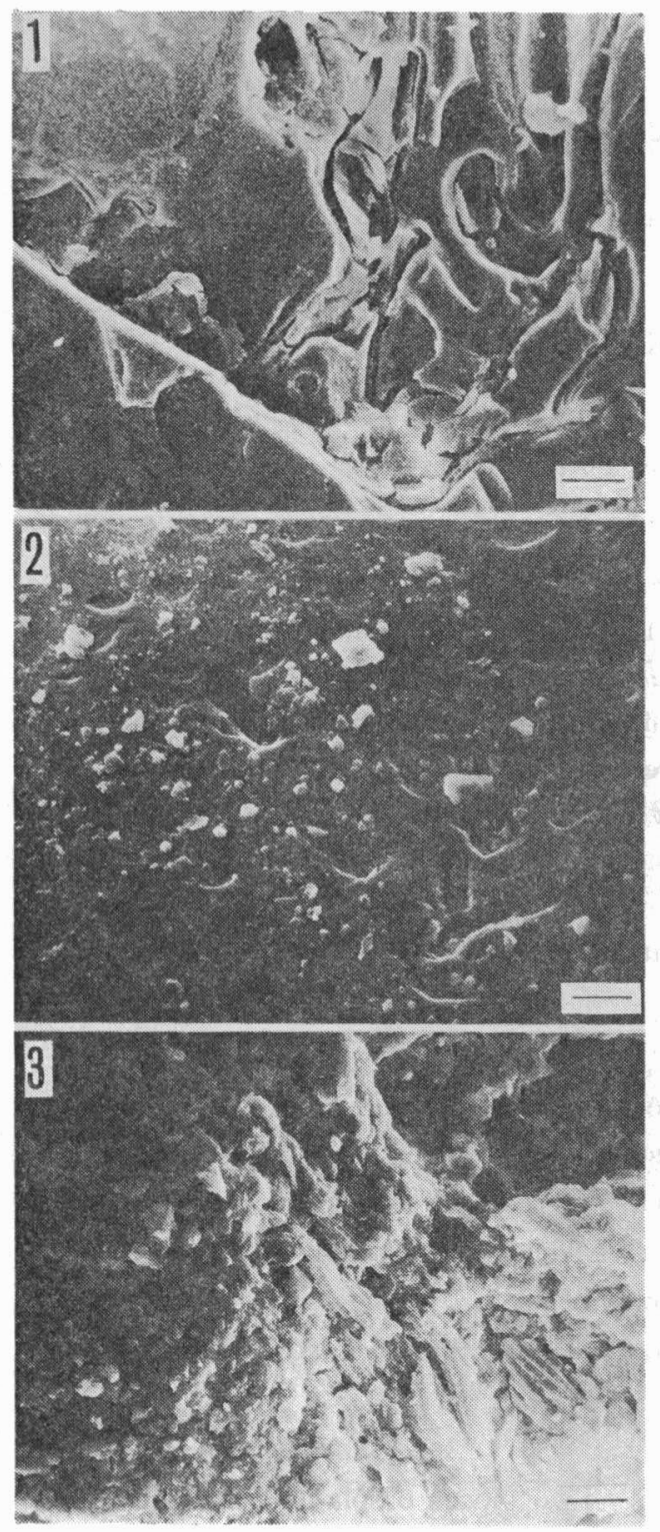

Fig. 1. SEM photographs of plagioclase, 1

(O1-7). Scale is $10 \mu \mathrm{m}$.

1: Fresh plagioclase has smooth surface.

2: Incipient stage of weathering. Smooth crystal surface is chemically eroded in various ways and is engraved with etch pits or hollows.

3: In the advanced stage of weathering, allophane aggregate spreads all over surface. lower Daisen pumice collected ${ }^{4)}$ at Hiruzenbara, Okayma Pref. The two kinds of volcanic ash soils are expressed as 01-7 and $\mathrm{H} 20-13$, respectively, figures of $1-7$ being a location number of Okachi soil and figures of 20-13 that of the Hiruzenbara soil. O1-7 was characterized by the lower flux or the alpha-ray from it, and H20-13 by the higher flux. ${ }^{1)}$

Micromorphology of plagioclase in 01-7 and that in $\mathrm{H} \mathrm{20-13}$ revealed their specific forms of surface materials and their che-
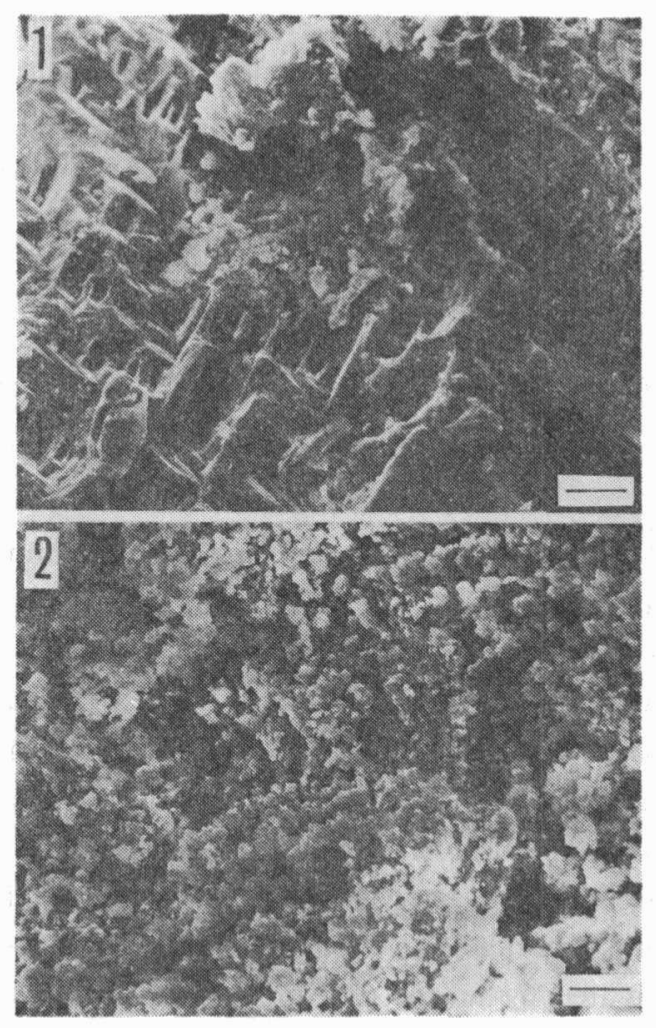

Fig. 2. SEM photographs of plagioclase, 2 (H2013). Scale is $10 \mu \mathrm{m}$.

1: Incipient stage of weathering is characterized by square hollows. Aggregate of allophane is partly growing on the surface.

2: The allophane aggregate covers almost of the surface. 
mical compositions peculiar to the forms. SEM photographs of the samples are shown in Fig. 1 and Fig. 2. Fresh bulk compositions of the plagioclase in $01-7$ and that in H20-13, which are shown in Table 1, however, are similar with each other by means of EPMA.4)

Table 1. Fresh bulk compositions of plagioclase in various kinds of volcanic ash soils.

\begin{tabular}{l|r|r|r} 
& \multicolumn{1}{c|}{1} & \multicolumn{1}{c}{2} & \multicolumn{1}{c}{3} \\
\hline $\mathrm{SiO}_{2}$ & 59.50 & 57.67 & 58.85 \\
$\mathrm{Al}_{2} \mathrm{O}_{3}$ & 26.12 & 28.04 & 27.02 \\
$\mathrm{Fe}_{2} \mathrm{O}_{3}$ & 0.13 & 0.12 & 0.10 \\
$\mathrm{CaO}$ & 6.82 & 7.37 & 7.40 \\
$\mathrm{Na}_{2} \mathrm{O}$ & 7.01 & 6.26 & 6.37 \\
$\mathrm{~K}_{2} \mathrm{O}$ & 0.23 & 0.23 & 0.25 \\
\hline Total & 99.81 & 99.69 & 99.99 \\
\hline
\end{tabular}

1), 2), 3), plagioclase.

The surfaces of the plagioclase samples from $01-7$ and $\mathrm{H} 20-13$ were smooth in appearence, but fragile due to weathering. Small pieces of the samples were easily crushed into fine powders with fingers.

\section{Secondary ion emission mass spec- trometry of plagioclase}

Plagioclase in 01-7 and that in $\mathrm{H} 20$ 13, later on expressed as only 01-7 and $\mathrm{H} 20-13$, respectively for simplicity were examined by using an IMA-2 ion microprobe analyzer. ${ }^{5,6)}$ No other pretreatment of the samples was performed than separation from the surrounding volcanic ash soils. After the separation, the samples were kept long enough on silica gel in a desiccator. As soon as the sample was taken out of the desiccator, it was fixed on a sample holder with silver paste at the back side of it, and was installed in the apparatus. Measurements were made under the vacuum of $2 \times 10^{-8}$ Torr. Surface peeling of the samples was made with $\mathrm{Ar}^{+}$ion beam, the current density of which was uniformly maintained over the bombarded surface area during the measurement, and was confined as low as possible, especially in examining the top layer of the surface. The diameter of the bombarding beam spot was $200 \mu \mathrm{m}$. The ion acceleration voltages were $5 \mathrm{kV}, 7 \mathrm{kV}, 10 \mathrm{kV}, 12 \mathrm{kV}$ and $15 \mathrm{kV}$. The effective energies available for peeling were $2 \mathrm{keV}, 4 \mathrm{keV}, 7 \mathrm{keV}, 9 \mathrm{keV}$ and $12 \mathrm{keV}$. The top layer of the surface was examined with lower energy ions, and the deep bulk with higher energy ions.

\section{Results and Discussion}

The secondary ions emitted from 01-7 under the surface peeling at various energies are shown in Table 2, where ions are arranged in the order of relative intensity for all the energies. Relative intensity sequence $\left[\mathrm{Al}^{+}, \mathrm{Si}^{+}, \mathrm{Ca}^{+}, \mathrm{Na}^{+}\right]$seen at $2 \mathrm{keV}$, the lowest energy in the present measurements, is peculiar to the superficial surface, where aluminum-rich composition was observed by means of SEM. ${ }^{4)}$ Sequence $\left[\mathrm{Al}^{+}\right.$, $\left.\mathrm{Na}^{+}, \mathrm{Ca}^{+}, \mathrm{Si}^{+}\right]$seen at $4 \mathrm{keV}$ is attributed to layers not so thick following the superficial surface. Sequence $\left[\mathrm{Na}^{+}, \mathrm{Al}^{+}, \mathrm{Ca}^{+}, \mathrm{Si}^{+}\right]$ seen at the energies of $7 \mathrm{keV}, 9 \mathrm{keV}$ and $12 \mathrm{keV}$ is responsible for the deep bulk, where sodium-rich composition without weathering was observed by means of EPMA.4) These sequences are entirely the same during $30 \mathrm{~min}$ measurements at all the energies. 


\section{Aratan i and K. Tazaki}

Table 2. The secondary ion emission from 01-7 under the surface peeling at various energies

\begin{tabular}{|c|c|}
\hline $\begin{array}{l}\text { Peeling } \\
\text { energy } \\
\text { (keV) }\end{array}$ & $\begin{array}{l}\text { The secondary ions and their } \\
\text { relative intensities* }\end{array}$ \\
\hline 2 & $\mathrm{Al}+(100), \mathrm{Si}+(20), \mathrm{Ca}+(15), \mathrm{Na}+(10)$ \\
\hline 4 & $\mathrm{Al}+(100), \mathrm{Na}+(50), \mathrm{Ca}+(20), \mathrm{Si}+(10)$ \\
\hline 7 & $\mathrm{Na}+(100), \mathrm{Al}+(45), \mathrm{Ca}+(30), \mathrm{Si}+(15)$ \\
\hline 9 & $\mathrm{Na}+(100), \mathrm{Al}+(55), \mathrm{Ca}+(35), \mathrm{Si}+(15)$ \\
\hline 12 & $\mathrm{Na}+(100), \mathrm{Al}+(75), \mathrm{Ca}+(45), \mathrm{Si}+(20)$ \\
\hline
\end{tabular}

The results on H20-13 are shown in Table 3 in the same way as in the Table 1. Secondary ion emission behavior in this case is different between at the beginning and at the end of $30 \mathrm{~min}$ measurement. shows that the bulk composition of $\mathrm{H} 20-13$ is also aluminum-rich, and that the weathered layers of $\mathrm{H} 20-13$ are too thick to be peeled off under the moderate condition peeling.

The different behavior of secondary ion emission between 01-7 and H20-13 leads us to the conclusion that the weathered layers of 01-7 are comparatively thin, and the aluminum-rich composition of the top surface rapidly changes to the sodium-rich composition of the fresh bulk; on the contrary, the weathered layers of $\mathrm{H} 20-13$ are thick, reaching the deepest bulk with aluminumrich composition. These differences are consistent with the results obtained by other related studies. ${ }^{1-4}$ )

Table 3. The secongary ion emission from $\mathrm{H} 20-13$ under the surface peeling at various energies.

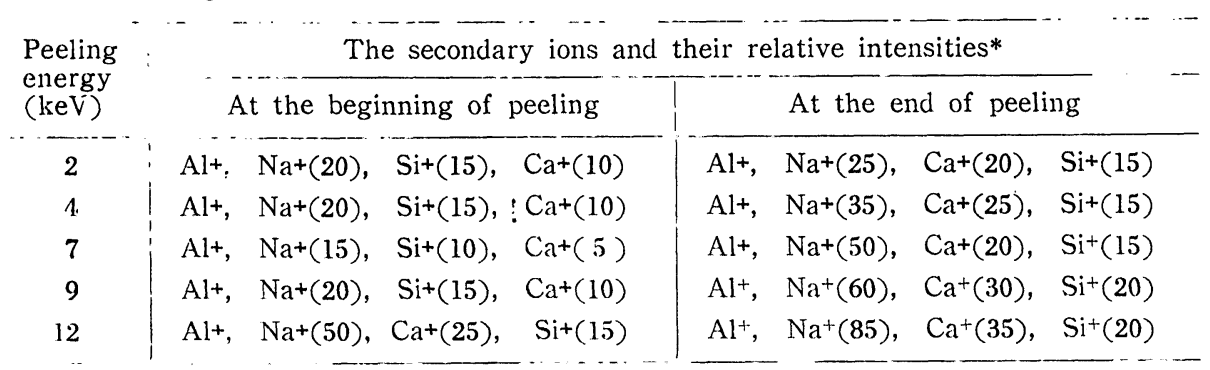

*Values of $\mathrm{Al}+\mathrm{ions}$ are $100 \%$ at the beginning and at the end of peeling measurements.

Relative intensity sequence $\left[\mathrm{Al}^{+}, \mathrm{Na}^{+}, \mathrm{Si}^{+}\right.$, $\left.\mathrm{Ca}^{+}\right]$seen at the beginning of $2 \mathrm{keV}$ peeling corresponds to aluminum-rich composition of the top surface. Appearance of sequence $\left[\mathrm{Al}^{+}, \mathrm{Na}^{+}, \mathrm{Si}^{+}, \mathrm{Ca}^{+}\right]$even at the beginning of $9 \mathrm{keV}$ peeling, however, reveals that the aluminum-rich composition is distributed in the bulk as well. Appearance of sequence $\left[\mathrm{Al}^{+}, \mathrm{Na}^{+}, \mathrm{Ca}^{+}, \mathrm{Si}^{+}\right]$at the beginning of 12 $\mathrm{keV}$ peeling and at the end of every run

\section{Acknowledgements}

The authors thank Mr. K. Nakamura, Naka Works, Hitachi Ltd., for his courtesy in our measaurements by using the IMA-2 ion microprobe analyzer. The authors also thank Dr. T. Nozaki for his helpful discussion. 
Secondary Ion Emission Mass Ṡpectrometry of Weathered Plagioclase in Volcanic Ash Soils

\section{References}

1) K. Tazaki, M. Aratani and H. Otsuka, Abs. Ann. Meet. on Radioisotopes in the Physical Sciences and Industry, Tokyo, 13, 68 (1976).

2) M. Aratani and N. Saito, Abs. Ann. Meet. of The Mass Spectroscopy Soc. of Japan, Tokyo, 24, 27 (1976).

3) M. Aratani, Abs. International Conference on Atomic Collisions in Solids, Moscow, 7, 225
(1977).

4) K. Tazaki, Papers of the Institute for Thermal Spring Research, Okayama Univesity, No. 45, 11 (1976).

5) K. Nakamura, S. Aoki, Y. Nakajima. H. Doi and H. Tamura, Mass Spectroscopy, 20, 1, (1972).

6) K. Nakamura, H. Tamura and T. Kondo, Japan J. Appl. Phys., 13, 917 (1974). 